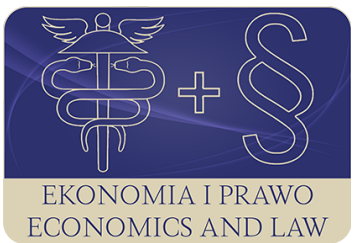

EKONOMIA I PRAWO. ECONOMICS AND LAW

Volume 20, Issue 4, December 2021

p-ISSN 1898-2255, e-ISSN 2392-1625

www.economicsandlaw.pl

ORIGINAL ARTICLE

received 30.05.2021; revised 01.12.2021; accepted 31.12.2021

Citation: Jaśkiewicz-Kamińska, S. (2021). The role of administrative courts in shaping the development directions of the sustainable development principle: remarks regarding case-law in environmental protection and spatial planning cases. Ekonomia i Prawo. Economics and Law, 20(4), 779-797. https://doi.org/10.12775/EiP.2021.046.

\title{
The role of administrative courts in shaping the development directions of the sustainable development principle: remarks regarding case-law in environmental protection and spatial planning cases
}

\section{SYLWIA JAŚKIEWICZ-KAMIŃSKA}

WSB University in Gdańsk, Institute of Law and Security Sciences, ul. Aleja Grunwaldzka 238 A, 80-266 Gdańsk, Poland

๑ sjaskiewicz@wsb.gda.pl

(D) orcid.org/0000-0003-2349-9820

\section{Abstract}

Motivation: This text presents the results of the process of juridization of the sustainable development principle in international, EU and national law, as well as the development of that principle with regard to the application of law practice.

Aim: At the same time, the text attempts to define the role of an administrative court as a body reinterpreting the sustainable development principle in environmental protection and spatial planning cases, bearing in mind both the ecological as well as social justice

outlook

Results: As a result, the study presented focuses on determining the impact of the administrative courts' established case-law on the application of the sustainable development principle by national public administration authorities.

Keywords: sustainable development principle; spatial planning; ecological justice; spatial justice JEL: Q01; R58 


\section{Introduction}

Sustainable development as an idea that is the goal and direction of modern societies' development striving to achieve "a fair system of cooperation over time, from one generation to the next" (Rawls, 1998, p. 47) in economic, social and environmental aspects emerged in 1987 (the Brundtland Report). The path from articulating the idea of sustainable development to establishing a clear definition of that concept or the expression of the principle of sustainable development expresis verbis in applicable legislation has come to an end neither in the area of international law nor in the area of supranational (regional) law or in the area of national law. Even more so, the normative status of sustainable development remains a concept of law in statu nascendi although scholarly writings and soft law for many years have been qualifying sustainable development as one of solidarity human rights and one of the principles of environmental protection law. This view is also reflected in the UN Resolution of 25 September 2015 - Transforming our world: the 2030 agenda for sustainable development (Agenda 2030) (UN, 2015).

The process of juridization of sustainable development keeps to the following scheme: from an idea, through the definition of sustainable development, to the principle of law or, alternatively, from an idea, through the principle of law, to the definition, depending on whether we look at the process of juridization from the perspective of international, supranational (regional) or national law. It should be emphasised at this place that not every axiological concept is subject to an effectively juridization, even if it obtains sectoral connotations. The more multidimensional it is, the more difficult it is for the legislature to precisely translate such an idea into the legal language in the form of legal norms or legal definitions, in such a way as to increase the likelihood that it will cease to be merely an empty slogan, abused for marketing purposes.

The legal status of the sustainable development principle in each of the three perspectives (international, regional, national) is not homogeneous and still leads to the reflection that the process of juridization has not been carried out in a comprehensive and effective manner, and therefore it is the responsibility of the authorities applying law to reinterpret sustainable development constantly and to prioritize it against other legally protected values. The reinterpretation should be carried out "in the spirit of time" in accordance with its leading idea - intergenerational justice - manifested not only in the already recognised ecological justice (UNSD, 1992), but also relating to the idea of spatial justice in spatial planning processes - reconstructed on the basis of Goal No 11 of Agenda 2030.

\section{Literature review}

The sustainable development principle has been a subject of many scientific monographs and articles in scientific journals. Over the course of more than 
30 years the academic dialogue has received far more critical remarks regarding the effectiveness of sustainable development concept juridization processes than those approving the legislators' actions in this regard. Legislative actions are considered not sufficient in that area (Kenig-Witkowska, 2017, pp. 64, 80), therefore, the original concepts of the sustainable development definition have appeared in scholarly writings. One example is "a new definition of sustainable development" presented by van Hees $(2014)^{1}$. In this place it should be mentioned that the concept of the sustainable development in scholarly writings was raised to the concept of law in statu nascendi in 2006 by Pyć (2006). This monography is undoubtedly an example of a deep sense of arising a new branch of law process.

\section{Methods}

The study is based mainly on doctrinal, descriptive, analytical and comparative legal research methods. It considers the perspective of the sustainable development principle evolution presented in the field of case law in environmental protection and spatial planning that leads the Author to the brief conclusions. The article includes two perspectives: the scientific polemics presented in books, during conferences and other scientific events ("law in books") and the judicial dialogue that reveals the "law in action" based on legally binding acts and political documents concerning sustainable development. The legal analysis gives the Author the opportunity to reconstruct not only the existing core of sustainable development upheld by present generations (chapter 4,5 of the text) but also enable indicating some remarks de lege lata and de lege ferenda (introduction, chapter 6 and conclusions) for future issues.

\section{Position and meaning of the sustainable development principle in international, EU and national law: between an idea of law and a legal norm}

According to Kenig-Witkowska (2018, pp. 29-30) the concept of sustainable development is still not of a normative nature in international environmental law "it only indicates an integrated approach to environmental, human and development issues". This is the case, despite the fact that the concept of sustainable development has already established itself in the context of law policy, as evidenced not only by the Rio Declaration (1992) but also many other subsequent documents made under the auspicies of the United Nations, such as the Mar-

${ }^{1}$ Sustainable development means "stimulating and encouraging economic development (e.g., more jobs, creativity, entrepreneurship and revenue), whilst protecting and improving aspects (at the global and European level) of nature and society (inter alia natural assets, public health and fundamental rights) for the benefit of present and future generations" (van Hees, 2014, p. 72). 
rakesh Agreement (1994) or the Paris Agreement (2015). In the judicial practice of the International Court of Justice the concept of sustainable development is treated as so-called soft law or as a modifying norm thereof and is used to balance norms in a conflict situation (Kenig-Witkowska, 2018, pp. 29-30; Ziemblicki, 2016, p. 149). In that sense, it performs similar functions to the principle of good governance.

Agenda 2030 is another step towards a new dimension of conceptualisation of sustainable development as the idea and principle, among others, in the area of spatial planning and development. Goal No 11 of Agenda 2030 very clearly articulates the need to carry out the space planning and development processes through:

- establishment of new safe settlement networks capable of adapting to different social and economic conditions, taking particular account of the needs of women, children, the elderly and the disabled;

- development of a sustainable public transport system that respects road safety rules, environmental protection and diverse social needs;

- increasing social participation in settlement planning processes;

- promoting universal access to safe public spaces and green spaces;

- strengthening the socio-environmental aspects of the links between the three dimensions of planning, including the relationship between urban, suburban and rural space planning;

- promoting settlement development taking into account climate change issues and holistic crisis management instruments inspired by Sendai framework for disaster risk reduction 2015-2030;

- promoting sustainable construction and resilient buildings utilizing local materials (UN, 2015).

In EU policy as well as primary and secondary EU law, the concept of sustainable development also occupies an important place. In Article 2 of the Treaty on European Union (2012), sustainable development is referred to as one of the Union's goals, contributing to the system of values approved and implemented by that organisation. It is said in the scholarly writings that, at the EU level, sustainable development arises from the principle of protection of human dignity and the common good. In primary legislation sustainable development appears as a goal, an obligation and the principle of law in various contexts, most often related to environmental protection (among others: Charter of Fundamental Rights of the European Union (2012, Article 37), Treaty on European Union (2012, Article 3 and Article 21), Treaty on the Functioning of the European Union (2012, Article 11 and Article 191). The concept of sustainable development is of normative nature here, but it is difficult to clearly define its content (EU primary law does not define sustainable development) (Skryt \& Klimska, 2019, pp. 186-187).

In the literature opinions have been raised that the reconstruction of the sustainable development principle in EU law takes place on the basis of instruments of international organisations (e.g. Agenda 2030), the text of the Treaty provi- 
sions, the Charter of Fundamental Rights of the European Union (2012) and case-law of the Court of Justice of the European Union (CJEU). In this way, the sustainable development principle focuses primarily on:

- obligation to rationally make use of natural resources,

- the precautionary principle,

- social participation,

- access to environmental information,

- the principle of good administration,

- the principle of integration.

The sustainable development principle, as read in the above-mentioned contexts, has been the subject of numerous decisions by the CJEU, as can be seen from the following cases: C-180/96, C-371/98, C-318/98, C-513/99 (Skryt \& Klimska, 2019, pp. 192-193).

In national law, the sustainable development has, above all, well-established connotations with environmental protection law. This is evidenced not only by the provisions of the Environmental protection law (2001), but above all by the Constitution of the Republic of Poland (1997). In the Basic Act, the sustainable development appears as a meta-norm in Article 5 (the principle of environmental protection and sustainable development), which seems to set the fundamental direction for the interpretation of the sustainable development principle. From that perspective, the sustainable development has been associated primarily with eco-development or integrated development (Olejarczyk, p. 121). However, the absence of the sustainable development definition in legislation of the constitutional status does not, however, authorise it to be interpreted in the light of Article 3(50) of the Environmental protection law (2001). The view by Łętowska (2006, p. 353) from which it is clear that "(...) while the use of the Constitution of the Republic of Poland (1997) for the interpretation of an ordinary statute is justified, the reverse reasoning is doubtful" seems to be significant in that respect.

The legal status of the sustainable development principle in the constitutional terms remains controversial. While it can be claimed agreeably that this principle is normative in that regard, its meaning as a principle of law is not that clear. Whether it is a systemic principle relating to aspects which may go beyond environmental protection (which might be indicated by, among others, comma in the text of Article 5 of the Constitution of the Republic of Poland (1997), or whether it is a political principle, or perhaps a general clause constituting an interpretation directive for legislation, remains in dispute. The answer to this question should be searched for in the views of authorities which apply the law, as well as the rulings of the Constitutional Tribunal and administrative courts.

The dilemma also remains whether, as a result of the process of juridization of sustainable development in national legislation we can talk about forming one single sustainable development principle or a set of principles that make it. Pawłowski (2015, pp. 93-94), emphasises that the sustainable development in the view of UN instruments is presented as a kind of an interdisciplinary 
programme, as a bundle of principles, while from a national perspective it is, among other principles adopted in The Polish national environmental policy (i.e. the prevention principle, the principle of equal access to the environment, the polluter-pays principle, the best available techniques - BAT, etc.), one single principle with many contexts, not just environmental ones, the principle that underpins the establishment of rights for present and future generations, taking into account the need to achieve four fundamental objectives: maintaining the quality of the environment, the safety of people, human well-being, holistically perceived justice. In this approach, the sustainable development ceases to be merely an eco-development as seen through the eyes of the legislator in $1994^{2}$. In the administrative law scholarly writings, the sustainable development principle becomes a general principle of administrative law which, as emphasised by Zimmermann (2016, p. 166), should be filled with content not only in the law-making process, but also, and perhaps above all, in the process of applying law.

The Constitutional Tribunal, in its judgement of 6 June 2006, took a new look at the sustainable development principle, denying that this principle is merely a "legislative illusion" and it was intended to address environmental protection or spatial planning issues only. The Tribunal emphasised that "the principles of sustainable development include not only the protection of nature or shaping of spatial governance, but also due concern for social and civilisational development, linked to the need to build an appropriate infrastructure necessary for life of humans and individual communities, taking into account civilisational needs. Therefore, the idea of sustainable development includes the need to take into account various constitutional values and to balance them accordingly" (Constitutional Tribunal judgement, 2006, K 23/05).

\section{The sustainable development principle in case-law of administrative courts in environmental protection law cases}

The sustainable development principle in terms of the provisions of the Environmental protection law (2001, Article 1 and Article 2) acquires the status of a general principle of environmental law. Subsequently, it appears in 14 other places of that legal act, which seems to confirm its significance as a principle throughout the entire environmental law system. Namely, in Article 3(13) of the Environmental protection law (2001) the legislator makes the sustainable development principle a directive for taking actions for rational development of the environment and management of natural resources; in Article 8 of the Environmental protection law (2001) the legislator promotes the idea of sustainable development

2 Sometimes in scholarly writings the views are raised relating to the origins of the sustainable development as a concept which is a 'successor' of the eco-development term used in the resolution of the Sejm of the Republic of Poland of 10 May 1991 on the national environmental policy and subsequently established by the Act on spatial development (1994) (cf. Olejarczyk, 2016, p. 127). 
as a guideline for creating policies, strategies, plans and programmes relating to (respective industries i.e. energy, transport, land-use planning (spatial planning - author's remark) policies. Article 13 of the Environmental protection law (2001) focuses on the order to develop an environmental policy in line with the sustainable development principle; in Article 7l(1) of the Environmental protection law (2001) the legislator introduces an obligation to take into account the sustainable development principle as a basis for drawing up and updating the concepts of national and voivodeship development strategies, as well as spatial planning studies and plans; Article 77(1) of the Environmental protection law (2001) calls for the sustainable development to be covered in curricula of general education for all types of schools; Article 80 of the Environmental protection law (2001) prohibits the creation of advertisements and other types and forms of product and service promotion in such a way as to promote a consumption model in contradiction with sustainable development; Article 388 of the Environmental protection law (2001) makes the concept of sustainable development a point of reference for the actions taken by the State Environmental Protection Council; Article 400a (1)(32) of the Environmental protection law (2001) refers to the promotion of the sustainable development principle in parallel to environmental education; Article 400o of the Environmental protection law (2001) requires to link the statutory actions undertaken under the National Fund for Environmental Protection and Water Management and the Voivodship Funds with such use of the funds derived from them to pursue the principle of sustainable development.

In Article 3(50) of the Environmental protection law (2001) the legislator explains the term 'sustainable development' as: "such socio-economic development which integrates political, economic and social actions, while preserving the natural equilibrium and the sustainability of basic natural processes, with the aim of guaranteeing the ability of individual communities or citizens, of both the present and future generations, to satisfy their basic needs". However, for the reconstruction of the concept of sustainable development based on Article $3(50)$, that definition does not appear to be sufficient in the context of understanding its position as a principle forming the environmental protection law system. Even more so, that definition should not, without the statutory authorisation (among others Article 2(2) of the Act on spatial planning and development (2003)), give rise to the interpretation of that concept in different contexts. Nor should it constitute grounds for interpreting the provisions of constitutional status, but should merely fulfil the demand for compliance with constitutional provisions. In view of the above, the analysis of case-law remains the right direction for the reconstruction of both the concept of sustainable development and the sustainable development principle.

WojewódzkiSąd Administracyjny (the Voivodeship Administrative Court, WSA) in its judgement of 27 November 2008 in the case relating to the assessment of the appropriateness of the consent and arrangements issued by the Voivode of the Municipality of Z., the State Poviat Sanitary Inspector and the State 
Voivodeship Sanitary Inspector respectively in respect of the investment in the form of the construction of a poultry farm in the Municipality of B. for 38000 broiler chickens, confronted the arrangements made with the sustainable development principle, making it one of the elements justifying the contestation of the consent to the investment in question. As it held in the case, the opposition of the residents regarding the proposed poultry farm investment has not been given the due regard, since the residents raised a complaint, according to which those applying for permission to build the farm have circumvented law by concealing information on the accumulation of odours and "other ailments" resulting from the fact that there were more plots of land in the immediate vicinity where the animals were kept. The omission, among others, of that fact had been, according to the administrative court, relevant for the investment under examination, and in particular, for the reliability of the environmental impact report that had been drawn up in that respect and gave rise to giving the consent to the investment in question. WSA also argued that a burdensome neighborhood, generating odours and noises, could cause somatic diseases (allergies, broncholiths), but also mental obsessions resulting from long-term staying in an environment full of odours. Failure to take those circumstances into account and errors in the report should be considered not only in the category of procedural irregularities (Code of administrative proceedings, 1960, Article 7, Article $77 \$ 1$ and Article 107\$3) but also substantive-legal ones in the form of violation of the constitutional principle of sustainable development, as well as the provisions of the Environmental protection law (2001) (WSA in Gorzów Wielkopolski judgement, 2008, II SA/Go 510/08).

WSA, in that judgment, described the role of the constitutional principle of sustainable development as a "directive for interpretation" useful in resolving "doubts about the scope of responsibilities, the type of responsibilities and the way in which they are implemented (...)". On the other hand, when addressing the sustainable development principle under the provisions of the Environmental protection law (2001), it emphasized that based on that case “(...) the sustainable development principle is used to resolve conflicts between competing values, where one is the environment and its protection and the other is economic freedom based on private ownership as referred to in Article 20 of the Constitution of the Republic of Poland (...)".

In a similar vein, WSA in Warsaw, heard the complaint of the inhabitants of the village of N., which dealt with an action against the decision of the Minister of Environment agreeing on conditions for the implementation of the investment of constructing an express road to pass through the Municipality of N. at one of its sections. Acting in accordance with the provisions of the Environmental protection law (2001) and after obtaining the opinion of the Minister of Environment, the Voivode issued an environmental decision on the implementation of the investment concerned under one of the options specified in the environmental impact report, but other than that indicated by the applicant. The option of building the road approved by the Minister of Environment in the arrange- 
ments was the best option from the point of view of the environmental protection (as well as for natural habitats, cultural monuments, human health and technical conditions of the investment implementation), although less economically or socially optimal. According to the approved option, the construction of acoustic screens was provided for at one of the road sections, to which the inhabitants of the village of N. refused to agree. WSA in Warsaw, when analysing the merits of the complaint, referred to the issue of the choice of option for the implementation of the investment, taking into account Article 55 of the Administrative Environmental protection law (2001), which, as it held, an obligation concerning the need to choose absolutely the best option from the point of view of environmental protection was not apparent. As it stated, "it is not apparent from the wording of that provision (...) that the implementation of the investment without taking into account any other conditions is an absolute requirement, in view of the need to protect the environment. In the case of road construction, these could include, among others, social considerations. (...) Economic considerations, which include the economic costs of implementing an investment of a particular option, may also be important (...). The Polish legal system has not established the principle of primacy of environmental protection over any other considerations" (WSA in Warsaw judgement, 2010, IV SA/Wa 876/09).

In the present case, however, WSA in Warsaw emphasized the need to justify the choice of a particular option, which means that it is necessary to identify the most environmentally beneficial option and, if another option is chosen, to indicate the conditions which lead to the choice of a different, more optimal manner of implementing the investment, with a precise indication and description of other reasons underlying such a choice. The most environmentally beneficial option does not have to be the best option for the investor or the local community. It is sufficient that it is optimal for the environment and takes into account other relevant interests and factors in a balanced manner. "The authority eventually adjudicating in the case assesses the facts and, where an environmentally optimal option has not been chosen, it shall consider whether the assumed stronger interference with environmental resources is acceptable (i.e. justified in the context of the sustainable development principles)" (WSA in Warsaw judgement, 2010, IV SA/Wa 876/09).

The position of WSA in Warsaw submitted in that judgment, is confirmed by the subsequent decisions on the assessment of the environmental impact reports results, including in particular, as regards drawing the conclusions from the analyses contained therein. In the judgment issued by WSA in Warsaw (2013, IV SA/Wa 2734/12) a complaint in relation to the environmental decision issued by the General Director of Environmental Protection also concerning the construction of a national road passing through several localities has been raised. In the case concerned, the inhabitants, among many complaints raised, first of all, raised the objection of improper public consultation and unreliable inference based on the outcome of those consultations, as well as other elements contained in the environmental impact report (at this point, it should 
be noted that the authority hearing the case on appeal referred the case back for review in order to remedy the alleged deficiencies which, according to the applicants, had not been implemented). The inhabitants did not approve of any of the road construction options presented in the report, nor did they accept the so-called zero option (non-implementation of any of the options). They argued that both during that road construction stage and its operation, the impact would be clearly negative and that the measures to minimise that negative effect proposed by the investor were insufficient. WSA in Warsaw rejected the allegation that the report presented an insufficient number of options which would enable a substantive assessment of the respective options for implementing the investment in question. At the same time, it has that the environmental analyses that had been carried out did not give a clear answer to the question - which option would be most favourable from an environmental point of view. According to the court, the option indicated by the investor would have the least conflict with forest and wooded areas, as well as with protected areas. At the same time, it stated that: "each option will provoke opposition from a particular group of the public, since it is not possible to run a conflict-free express road in urban areas". According to the court, the authorities have collected evidence in the case in a fair and complete manner and its assessment is not objectionable and does not infringe Article 7 and Article 77 of the Code of administrative proceedings (1960). That court emphasised that "the Polish legal system has not established the principle of the primacy of environmental protection over other considerations, and the framework for taking environmental considerations into account is determined by the sustainable development principle (...)". According to that principle, "the role of environmental authorities is to balance the profits and losses arising from the investment undertaken", and the role of the courts is to review whether those activities have been carried out in a fair and consistent manner both in terms substantive and procedural law, as well as within the powers conferred on them (ultra vires control) (WSA in Warsaw judgement, 2013, IV SA/Wa 2734/12).

\section{The sustainable development principle as a prerequisite for judicial review of the planning autonomy limits}

In the Act on spatial planning and development (2003) the concept of sustainable development is included in two places, i.e. in Article 1(1) (2) and in Article 2(2). In the first case, it appears as a general principle, which, in addition to the principle of spatial governance, is one of the two main principles of spatial policy-making. In the latter case, on the other hand, it appears as a legal definition with a reference to Article 3(50) of the Environmental protection law (2001), which at the same time indicates its systemic nature. Through planning law institutions such as a local plan or a decision on the land development conditions the sustainable development principle, within the meaning of the Act on spatial planning and development (2003), also affects the construction process indirectly 
(although in the Construction law (1994), sustainable development is not referred to expresis verbis at all).

The sustainable development principle under the Act on spatial planning and development (2003) is reflected in:

- the possibility of restricting the freedom of development (as well as indirectly construction freedom);

- transparency of the carrying out of planning procedures;

- participation of the public in work on planning acts.

In the administrative law scholarly writings, the legal nature of spatial policy-making principles (Act on spatial planning and development, 2003, Article 1(2)) has not been clearly identified. There are views that they may be an example of reference provisions (as was the case under the Act on spatial planning and development (2003)) or provisions containing indefinite, indeterminate phrases (the dominant view in the scholarly writings). Therefore, the recognition of the latter status necessitates that they have to be considered as directly binding and being able to constitute a self-contained basis for the reconstruction of legal norms, which makes both principles part of a properly conducted planning procedure. The view that because of their indefinite nature, those provisions cannot constitute a self-contained legal basis for a decision on the land development conditions, for a decision on setting the location for a public purpose investment or a basis for refusal to agree on a draft local spatial development plan, is consistent. The reconstruction of such notions as spatial governance or sustainable development must therefore be carried out on a case-by-case basis, with reference to particular facts of the case (Niewiadomski, 2021, pp. 2-3).

The role of public administration authorities in achieving the sustainable development principle is undeniable here. The literature even emphasises that public administration authorities, including in particular authorities of local government units, at the regional and local level, are benchmarks for maintaining integrated governance in the sustainable development process (Jańczuk, 2015, p. 248). Therefore, sustainable development within the meaning of the provisions of the Act on spatial planning and development (2003) means more than a concept aimed at ensuring environmental security in the narrow sense. An example could be the resolution of WSA in Olsztyn of 6 October 2020 , where the court assessed, on the basis of an action brought by one of the agricultural producers against the resolution of the Municipal Council on passing a local spatial development plan, whether there had been a transgression of the limits of the so-called planning autonomy resulting in restriction of the ownership right and the freedom to carry on agricultural activities (WSA in Olsztyn judgement, 2020, II SA/Ol 243/20). In the NSA (the Supreme Administrative Court) judgement of (2012, II OSK 1144/11) it is held that sustainable development means actions improving the condition of the environment enabling its further development (cf. Błażewski, 2015).

In the case under consideration WSA in Olsztyn had to assess whether, as a result of introducing to the local plan by the Municipal Council, the provi- 
sion that prohibited breeding and rearing of animals above $210 \mathrm{LCU}$, while allowing to conduct such activities up to 60 LCU (large convert units) there has been a transgression of planning autonomy or not. The need for such an assessment was caused by a complaint submitted by one of the agricultural producers, who had planned to carry out such activities on a larger scale. In the present case, the applicant claimed that, prior to the adoption of the new local plan, it had obtained three environmental decisions approving an increase in the intensity of his operation with regard to the construction of investor buildings and, in the light of that argument, for example, he was entitled to complain to the Municipal Council about failure to take into account the arrangements made so far resulting from the spatial development study in respect of land intended mostly for agricultural and forestry purposes, by introducing provisions on possible building of small residential dwellings and thus introducing restrictions on the permissible volume of agricultural production.

As WSA in Olsztyn emphasized, a spatial development plan may enter the sphere of exercise of ownership right, as evidenced by the Article 6(l) the Act on spatial planning and development (2003), since the right of ownership is not an absolute right and may be limited (Constitution of the Republic of Poland, 1997, Article 64(3)). The task of the Municipal Council is to balance the equivalent interests in accordance with the principle of proportionality and the precautionary principle. These interests include the public interest, the legitimate interests of individuals, environmental considerations and other reasons requiring "reconciling" for reasons of the sustainable development principle. As a result of numerous protests of residents demanding restrictions on the intensity of animal husbandry and livestock farming, up to 40 LCU, the Municipal Council, as the court points out, in the absence of legislation on air pollutants limit values and the assessment of fragrances (odours), had to assess their admissible values. According to WSA the solution adopted in that respect was a compromise and, in line with the sustainable development principle, "made spatial planning and development a feature of permanent combination of environmental and economic development requirements". The solutions adopted by the Municipal Council respected the sustainable development principle, both in the form of Article 1(1)(2) of the Act on spatial planning and development (2003), as well as under Article 5 of the Constitution of the Republic of Poland (1997) (WSA in Olsztyn judgement, 2020, II SA/Ol 243/20). According to settled case-law "the application of that principle makes it possible to take account of the links between the environment and the requirements of spatial governance. For this reason, the prevention of threats to sustainable development implementation requires, under the procedure of adopting a local plan, preventive measures to be taken at source of the threats origins" (NSA judgement, 2015, II OSK 2233/13).

The limits of the planning autonomy are set by the sustainable development principle. Wherever there is a conflict of interest, where considerations arising from the requirements of spatial governance, environmental protection needs, public interest needs as well as economic aspects and property rights intersect, 
public administration authorities balance them in accordance with the principle of proportionality and respecting the principle of equal treatment of all entities of any possible conflict of interest (cf. NSA judgement, 2018, II OSK 1281/16). Where one of the owners of a property situated in the area covered by a new local plan complains about discriminatory practices made in the case of conversion of land designation from various and forest land to forest and for residential purposes land without the possibility of converting forest land to land for residential purposes, the municipality authority must carry out a thorough analysis and assess the way in which the land has been used so far, resulting from both land registers and the provisions of the study, and take into account the arrangements made as well as the actual condition of the property located on the area subject to planning (WSA in Gdańsk judgement, 2020, II SA/Gd $418 / 20)$.

As WSA in Gdańsk assessed, the City Council, by adopting a new local plan, sought to establish new investment opportunities in the area of the Municipality, but while maintaining the sustainable development principle introduced to the text of the Study and repeated in the solutions of the plan. With such assumptions, it was obvious that not the whole area of the former military unit could be used for tourist development (WSA in Gdańsk judgement, 2020, II SA/Gd 418/20). Accordingly, the applicant's assertion that such development of the area according to which the directly adjacent plots of land are treated unequally in relation to the possibility of carrying out investments in the form of tourist and leisure facilities is not justified. It results from the presented concept of land development, justifies in the planning documentation, that the development directions shaped therein are in line with the sustainable development principle. There can be no infringement of substantive or procedural law, nor have the limits of planning autonomy been exceeded by the excessive and unjustified interference of the public authorities in the exercise of property rights. As a result of the findings following from the new local plan, it is not apparent that the applicant could not exercise her ownership right at all. What is more the restrictions imposed were admissible and proportionate, as well as compatible with the sustainable development principle (WSA in Gdańsk judgement, 2020, II SA/Gd 418/20). Balancing of individual rights (interests of citizens) and the public interest in the planning procedures undertaken shall be carried out in compliance with respect for constitutionally guaranteed rights, taking into account the necessary restrictions on those rights and freedoms applicable in a democratic state of law and in accordance with the principle of proportionality, understood as a prohibition of an excessive interference with the values protected by law (NSA judgement, 2017, II OSK 950/17; 2020, II OSK 971/19).

\section{Conclusion}

The national legislator takes into account the proposals focused on Goal No 11 of Agenda 2030, manifested, among others, in Article 1(4) of the Act on spa- 
tial planning and development (2003) (the rules for the developing new residential facilities) and developing the proposals referred to in Article 1(4) of the Act on spatial planning and development (2003), the Act on facilitating the preparation and implementation of housing and accompanying investments (2018) shaping special solutions in the area of housing, as well as Article 2(4) of the Act on ensuring accessibility for persons with special needs (2019) - relating to the need for "universal planning".

National public administration authorities apply the sustainable development principle in connotation with environmental protection and spatial planning norms, also as guidelines in the process of establishing local legislation in those areas. In the process of applying the law, the sustainable development principle, alongside the principle of spatial governance, embodies the idea of a sustainable space, gaining both environmental and social context. The effects of the implementation of the sustainable development principle manifested in organising activities of public administration authorities may be measurable, provided that there are indicators that need to be published.

Administrative courts review whether public administration authorities interpret the sustainable development principle correctly and optimally, reinterpreting that principle on the basis of specific environmental cases, verifying the correctness of the spatial planning process in the procedures for adopting local plans, in revitalisation processes or under the investment and construction procedures. Those courts, on the one hand, preserve the settled case-law, and on the other hand, they create new directions for interpreting the sustainable development principle in the light of any new aspects of that principle, confirming not only the normative nature of that principle, but also its broad scope. The judicial activity of the national administrative courts developed so far is close to making the sustainable development principle a norm which embodies the idea of spatial justice.

\section{References}

Błażewski, M. (2015). Ochrona zrównoważonego rozwoju oraz ładu przestrzennego w procesie budowlanym. Acta Universitatis Wratislaviensis: Prawo, 3656, $121-129$.

Charter of Fundamental Rights of the European Union (OJ C 326, 26.10.2012). Consolidated version of the Treaty on European Union (OJ C 326, 26.10.2012). Consolidated version of the Treaty on the Functioning of the European Union (OJ C 326, 26.10.2012).

Jańczuk, L. (2015). Samorząd terytorialny jako benchmark ładu zintegrowanego w procesie rozwoju zrównoważonego. Prace Naukowe Uniwersytetu Ekonomicznego we Wroctawiu, 391, 248-256. https://doi.org/10.15611/ PN.2015.391.26. 
Kenig-Witkowska, M. (2017). The concept of sustainable development in the European Union policy and law. Journal of Comparative Urban Law and Policy, 1(1), 64-80.

Kenig-Witkowska, M. (2018). Projekt globalnego paktu dla środowiska. Retrieved 18.08.2021 from https://www.clientearth.pl/media/q2rpn3jo/2018-05-25-projekt-globalnego-paktu-dla-srodowiska-ce-pl.pdf.

Konstytucja Rzeczypospolitej Polskiej z dnia 2 kwietnia 1997 r. [Constitution of the Republic of Poland of 2 April, 1997] (Dz.U. 1997 nr 78 poz. 483) (Poland).

Łętowska, E. (2006). Promieniowanie orzecznictwa Trybunału Konstytucyjnego na poszczególne gatęzie prawa. In M. Zubik (Ed.), Księga XX-lecia orzecznictwa Trybunału Konstytucyjnego (pp. 353-376). Biuro Trybunału Konstytucyjnego.

Niewiadomski, Z. (Ed.) (2021). Planowanie i zagospodarowanie przestrzenne: kometarz. Beck.

Olejarczyk, E. (2016). Zasada zrównoważonego rozwoju w systemie prawa polskiego: wybrane zagadnienia. Przegląd Prawa Ochrony Środowiska, 2, 119140. https://doi.org/10.12775/PPOS.2016.013.

Pawłowski, A. (2015). Zasada, czy zasady, zrównoważonego rozwoju. Wschodni Rocznik Humanistyczny, 11, 85-96.

Pyć, D. (2006). Prawo zrównoważonego rozwoju. Uniwersytet Gdański.

Rawls, J. (1998). Liberalizm polityczny. PWN.

Skryt, A., \& Klimska, A. (2019). Ethical and legal conditions of sustainable development: the perspective of primary EU law and the case law of the Court of Justice of the European Union in matters of environmental protection. Scientific Papers of Silesian University of Technology: Organization and Management Series, 137, 187-197. http://dx.doi.org/10.29119/1641-3466.2019.137.12.

UN. (2015). Transforming our world: the 2030 agenda for sustainable development. Retrieved 18.08.2021 from https://sdgs.un.org/sites/default/files/publications/21252030\%20Agenda\%20for\%20Sustainable\%20Development\%20 web.pdf.

UNSD. (1992). Agenda 21. Retrieved 18.08.2021 from https://sustainabledevelopment.un.org/content/documents/Agenda21.pdf.

Ustawa z dnia 14 czerwca 1960 r. Kodeks postępowania administracyjnego [Act of 14 June 1960 Code of administrative proceedings] (Dz.U. $1960 \mathrm{nr} 30$ poz. 168) (Poland).

Ustawa z dnia 19 lipca 2019 r. o zapewnianiu dostępności osobom ze szczególnymi potrzebami [Act of 19 July 2019 on ensuring accessibility for persons with special needs] (Dz.U. 2019 poz. 1696) (Poland).

Ustawa z dnia 27 kwietnia 2001 r. Prawo ochrony środowiska [Act of 27 April 2001 Environmental protection law] (Dz.U. $2001 \mathrm{nr} 62$ poz. 627) (Poland).

Ustawa z dnia 27 marca 2003 r. o planowaniu i zagospodarowaniu przestrzennym [Act of 27 March 2003 on spatial planning and development] (Dz.U. $2003 \mathrm{nr} 80$ poz. 717) (Poland). 
Ustawa z dnia 5 lipca 2018 r. o ułatwieniach w przygotowaniu i realizacji inwestycji mieszkaniowych oraz inwestycji towarzyszących [Act of 5 July 2018 on facilitating the preparation and implementation of housing and accompanying investments] (Dz.U. 2018 poz. 1496) (Poland).

Ustawa z dnia 7 lipca $1994 \mathrm{r}$. o zagospodarowaniu przestrzennym [Act of 7 July 1994 on spatial development] (Dz.U. $1994 \mathrm{nr} 89$ poz. 415) (Poland).

Ustawa z dnia 7 lipca 1994 r. Prawo budowlane [The Act of 7 July 1994 Construction law] (Dz.U. $1994 \mathrm{nr} 89$ poz. 414) (Poland).

van Hees, S.R.W. (2014). Sustainable development in the EU: redefining and operationalizing the concept. Utrecht Law Review, 10(2), 60-76. https:// doi.org/10.18352/ulr.269.

Wyrok Naczelnego Sądu Administracyjnego z dnia 14 marca 2018 r. [NSA judgement of 14 March 2018] (II OSK 1281/16) (Poland).

Wyrok Naczelnego Sądu Administracyjnego z dnia 23 października 2012 r. [NSA judgement of 23 October 2012] (II OSK 1144/11) (Poland).

Wyrok Naczelnego Sądu Administracyjnego z dnia 25 listopada 2020 r. [NSA judgement of 25 November 2020] (II OSK 791/19) (Poland).

Wyrok Naczelnego Sądu Administracyjnego z dnia 6 lutego 2015 r. [NSA judgement of 6 February 2015] (II OSK 2233/13) (Poland).

Wyrok Naczelnego Sądu Administracyjnego z dnia 6 września 2017 r. [NSA judgement of 6 September 2017] (II OSK 950/17) (Poland).

Wyrok Trybunału Konstytucyjnego z dnia 6 czerwca 2006 r. [Constitutional Tribunal judgement of 6 June 2006] (K 23/05) (Dz.U. 2006 nr 106 poz. 720) (Poland).

Wyrok Wojewódzkiego Sądu Administracyjnego w Gdańsku z dnia 12 grudnia 2020 r. [WSA in Gdańsk judgement of 16 December 2020] (II SA/Gd 418/20) (Poland).

Wyrok Wojewódzkiego Sądu Administracyjnego w Gorzowie Wielkopolskim z dnia 27 listopada 2008 r. [WSA in Gorzów Wielkopolski judgement of 27 November 2008] (II SA/Go 510/08) (Poland).

Wyrok Wojewódzkiego Sądu Administracyjnego w Olsztynie z dnia 6 października 2020 r. [WSA in Olsztyn judgement of 6 October 2020] (II SA/Ol 243/20) (Poland).

Wyrok Wojewódzkiego Sądu Administracyjnego w Warszawie z dnia 18 kwietnia 2013 r. [WSA in Warsaw judgement on 18 April 2013) (IV SA/Wa 2734/12) (Poland).

Wyrok Wojewódzkiego Sądu Administracyjnego w Warszawie z dnia 30 czerwca 2010 r. [WSA in Warsaw judgement of 30 June 2010] (IV SA/Wa 876/09) (Poland).

Ziemblicki, B. (2016). Zrównoważony rozwój z perspektywy prawa międzynarodowego i europejskiego. Prace Naukowe Uniwersytetu Ekonomicznego we Wroctawiu, 452, 149-161. https://doi.org/10.15611/pn.2016.452.13.

Zimmermann, J. (2016). Prawo administracyjne. Wolters Kluwer. 


\section{Acknowledgements}

Author contributions: author has given an approval to the final version of the article.

Funding: this research was fully funded by the WSB University in Gdańsk.

Note: the results of this study were presented at the 8th International Conference Sustainable Finance \& Accounting: Economy, Ethics, Environment (April 19-21, 2021, Torun, Poland). 
